\title{
Reflexions sobre la vitalitat de l'ús del català entre els polítics valencians. Estudi a partir
} de Twitter

\author{
Reflexions over the vitality of the use of Catalan among Valencian politicians. An \\ overview of Twitter
}

\author{
Teresa Bellido Calduch \\ Universidá d'Uviéu \\ bellido.teresa@gmail.com \\ Aina Monferrer-Palmer \\ Universitat Jaume I \\ aina.monferrer@uji.es \\ Data de recepció: 27/03/18 \\ Data d'aceptació: 02/07/2018
}

\begin{abstract}
Resum
Les noves generacions s'informen cada vegada més per les xarxes socials i menys per mitjans convencionals com la televisió. Aquest fenomen podria convertir-se en una oportunitat per a les llengües minoritzades, si els generadors d'opinió pública les utilitzen i les fan tendència. És el que passa amb llengües com ara el català, entre les llengües del món amb més vitalitat a internet. S'ha analitzat l'ús que es fa del català entre els polítics d'àmbit valencià a Twitter. Partim de la idea que entre els polítics que fan servir el valencià existeix un biaix ideològic decantat cap a l'esquerra i cap al valencianisme. D'aquesta anàlisi, n'extraurem impressions, entre d'altres, sobre quin percentatge de líders d'opinió valencians utilitzen el català com a llengua vehicular per a piular; quina és la qualitat normativa de la llengua que utilitzen; i a quin biaix ideològic (generacional, temàtic...) pertanyen aquells que utilitzen el valencià a Twitter.
\end{abstract}

Paraules clau: líder d'opinió; tria lingüística; metàfora; tuit; ideologia.

\begin{abstract}
New generations are increasingly getting information from social networks and less by conventional media such as television. This phenomenon could become an opportunity for minority languages, as long as public opinion generators both use them and set that use as a trend. This is what is happening with Catalan, one of the languages with the strongest vitality on the Internet these days. We intend to analyse the use of Catalan among politicians in the Valencian context. We start from the idea that among the politicians who use Valencian, there is an ideological bias towards both left-wing positions and Valencianism. From this analysis, we will extract impressions on things such as the amount of Valencian opinion leaders that use Catalan as a vehicular language to tweet; the normative quality of the language they use; and their ideological bias (generational, thematic...).
\end{abstract}

Keywords: influencer; language choice; tweet; ideology; metaphor. polítics valencians. Estudi a partir de Twitter”. Revista Estudis Filològics i de Traducció (EFIT) 1: 207234. Doi: 10.7203/efit.1.16747 



\section{Esquema}

1. Introducció

2. Metodologia

3. Anàlisi quantitativa dels resultats

4. Anàlisi qualitativa dels resultats

4.1. Anàlisi qualitativa per categories temàtiques

4.1.1. Catalunya

4.1.2. Educació

4.1.3. Festes

4.1.4. Valencianisme

4.1.5. À Punt

4.1.6. Turisme

4.1.7. Pacte valencià contra la violència de gènere

4.2. Anàlisi qualitativa d'aspectes discursius

4.2.1. Els canvis de codi

4.2.2. L'humor

5. Conclusions

Bibliografia 



\section{Introducció}

Aquest estudi és una revisió de l'ús que fan els polítics valencians de Twitter. Hem adoptat un enfocament teoricometodològic a cavall entre els Media studies i la sociolingüística. Per començar, caldrà acotar la definició d'espai valencià de comunicació valencià. Josep Gifreu (2014) defineix un espai de comunicació segons quatre premisses: l'existència d'una llengua pròpia, d'un territori històric, d'uns rituals mediàtics determinats i de referents simbòlics propis.

En aquest sentit, el valencià hauria de ser un espai de comunicació, tot i que en els darrers anys ha estat especialment malmès sobretot pel que fa als rituals mediàtics, que s'han diluït per la manca de referents amb la desaparició de RTVV (el 29 de novembre de 2013) i la prohibició de les emissions de RTVC (el 17 de febrer de 2011). Aquestes accions han estat ideològicament dirigides pel govern del PP (1995-2015) i encara no han pogut ser revertides pel nou govern progressista, tot i que s'està treballant en aquesta direcció a hores d'ara (any 2018).

Tanmateix, al mateix temps que el govern valencià bloquejava tots els mitjans audiovisuals en català, apareixien i es consolidaven nous espais mediàtics en què l'ús del català al País Valencià era més que remarcable: especialment Twitter i Facebook. Per tant, la sobtada orfandat audiovisual dels valencians es va veure atenuada per aquests nous canals, en què el català apareixia com a llengua d'expressió dinàmica i bastant present. De fet, s'ha contrastat la capacitat històrica que han tingut els moviments dissidents (o les minories) de trobar noves vies d'expressió i d'acció. En paraules de Shirky (2016: 32):

Just as Luther adopted the newly practical printing press to protest against the Catholic Church, and the American revolutionaries syncronized ther beliefs using the postal service that Benjamin Franklin had designed, today's dissident movements will use any means possible to frame their views and coordinate their actions.

Entenent moviments dissidents en un sentit molt ampli de col·lectiu que no es troba representat (en aquest cas, convenientment) dins l'statu quo, coincidim amb Poell i Darmoni (2012: 2) que el desafiament en la recerca en social media és examinar aquestes tecnologies de comunicació com a part d'un procés complex que implica molts actors i moltes tecnologies. De fet, l'espai mediàtic valencià ha aconseguit superar les barreres diglòssiques i de persecució de 
la llengua i de la cultura en els mitjans audiovisuals tradicionals gràcies a la consolidació de la catosfera (l'espai mediàtic en català del blogging i del microblogging), en la qual la persecució política és molt més difícil i les fronteres culturals entre territoris de parla catalana es difuminen.

Segons Gifreu (2014: 166) Twitter i Facebook són dues xarxes socials de referència quant a l'ús del català. I concretament Twitter s'ha convertit en la xarxa política per antonomàsia dins la catosfera. Boyd, Golder i Lotan (2010: 1) defineixen Twitter com un servei de microblogging que permet als usuaris penjar missatges (tuits o piulades) de menys de 140 caràcters i que permet diverses pràctiques comunicatives, entre les quals hi ha la conversa entre dos individus, en grup o amb el públic en general.

Segons l'informe sobre l'ús del català de Plataforma per la Llengua de l'any 2017, Twitter és el 5è web més consultat als territoris de parla catalana. A més, nou dels deu webs més consultats tenen versió en català. Sis dels deu principals webs a internet tenen versió en català. De fet, el català és una llengua molt vital a les xarxes socials. A la Viquipèdia ja hi ha 500.000 entrades, més que en les versions àrab, finesa o turca d'aquest lloc web col·laboratiu. I el català es troba entre les llengües amb més vitalitat a la xarxa si es té en compte el número d'usuaris en relació amb el número de parlants que té la llengua.

Paral·lelament, la xarxa social Twitter és potser la preferida dels polítics. En altres xarxes, com ara Facebook o Instagram, els missatges polítics poden cansar abans els usuaris, que solen considerar-los intrusius. Però en el cas de Twitter, sembla que la política és un tema central i apreciat per la majoria d'usuaris, que no el consideren invasiu. Els polítics tenen alguns avantatges quan utilitzen Twitter com ara la rapidesa amb què s'informen de l'actualitat i alhora la manera sintètica (facilitadora de titulars i poc saturadora) amb què els polítics mantenen informada la societat a partir de l'esmentat canal. Aquesta tendència fou marcada en eleccions electorals als EUA, inicialment per Barak Obama, i s'ha consolidat més recentment amb la victòria de Donald Trump.

Així doncs, els polítics busquen ser líders d'opinió a Twitter i, amb l'ajuda de periodistes o d'influenciadors d'altres sectors que els repiulen aquells tuits més interessants, aconsegueixen 
expandir la seua veu amb més o menys èxit a través d'una xarxa social tan adequada per a la generació d'idees polítiques, així com per a la proliferació del debat ideològic. En aquest estudi, tractem de perfilar quin ús discursiu de Twitter fan els polítics valencians.

Concebem Twitter com un espai multilingüe. Quant a estudis previs que adopten aquest enfocament, Kim et al. (2014: 243) s'interessen pels usos en comunitats multilingües perquè consideren aquest fet crucial en quatre sentits: 1) la preservació de la llengua, 2) el capital social i qüestions de segregació, 3) l'estatus social i l'assimilació lingüística i 4) la selecció lingüística depenent del tema. Aquestes qüestions es tindran en compte en les nostres anàlisis.

\section{Metodologia}

Twitter té els seus punts forts i febles quant a la recerca en usos lingüístics. Segons Nobajas (2016: 93), posseeix un grau de penetració molt elevat i com a conseqüència és una font d'informació contínua i massiva a partir de la qual es pot treure informació rellevant. Entre les problemàtiques metodològiques que aquest autor destaca, hi ha les característiques demogràfiques dels usuaris de Twitter, els mètodes de localització dels tuits i la identificació de la llengua emprada. Cal no perdre de vista que Twitter no és un reflex significatiu del gruix de la societat. A més, tot i que ha introduït eines per a detectar les llengües en què estan escrits els tuits, només detecta 29 llengües i entre elles no hi és el català (2016: 97).

Per totes aquestes dificultats, considerem que la millor manera de què disposem d'analitzar dades de Twitter per a recerca en usos lingüístics és la qualitativa, amb el suport d'algunes dades numèriques. Més encara en un tipus de recerca com la nostra, en què treballem amb un gruix poc elevat de dades, no com en recerques massives de dades com ara Kim et al. (2014), Poell i Darmoni (2012) o Suh et al. (2010), entre d'altres, en les quals una recerca únicament quantitativa podria ser significativa i interessant. Per tant, coincidim amb Nobajas (2016: 99) que un cop s'ha emmagatzemat un corpus de piulades significatiu, es poden fer preguntes a mida i segons les necessitats de cada moment a quantitats ingents de dades que 
poden ajudar a obtenir una visió més profunda del món. Però coincidim també amb Hong et al. (2011: 521):

Finally, although our language detection algorithm is imperfect, we believe that automatic techniques like ours, even with their inherent shortcomungs, are complementary to manual coding methods. Both types of research methods are needed to study the explosive growth of social media.

Per tant, hem combinat la recollida manual de dades, alguns resultats numèrics i l'anàlisi crítica del discurs que es genera a Twitter a partir de textos breus que són baules d'una cadena dialògica, tot contrant-nos en les piulades dels polítics valencians més actius i influents en aquesta xarxa social.

D’acord amb el nostre marc teòric i amb les limitacions metodològiques esmentades, ens plantegem els següents objectius de recerca. L'objectiu general és estudiar l'ús de les llengües que fan els polítics valencians a la xarxa social Twitter. El primer objectiu específic és estimar quantitativament l'ús de les llengües per part de la mostra i trobar diferències entre grups. El segon objectiu específic és analitzar la qualitat d'eixe ús des d'una perspectiva discursiva i sociolingüística.

A més, ens basem en dues hipòtesis. La primera és que possiblement hi haja una correlació entre el biaix ideològic i la tria lingüística en el sentit de com més a l'esquerra, major ús del català i viceversa. La segona és que intuïm que hi haurà diferències entre la tria de temes (a través de les etiquetes o hashtags) i les estratègies comunicatives utilitzades segons el biaix ideològic.

La mostra objecte del nostre estudi ha estat composta pels alcaldes de municipis de més de 20.000 habitants (64), els diputats que conformen Les Corts Valencianes (99), els diputats al Congrés per les circumscripcions de Castelló (5), València (16) i Alacant (12), els Senadors per aquestes tres circumscripcions també (12 en total) i els Senadors per designació autonòmica (6). Pel que fa a la filiació política, 24 dels nostres subjectes pertanyia a Podem, 35 a Compromís, 69 al Partit Socialista, 19 a Ciudadanos i 60 al Partit Popular. 
Per a l'anàlisi quantitativa, hem calculat freqüències i hem elaborat gràfiques per observar tendències i diferències entre les variables, utilitzant el programa Statistical Package for the Social Sciences (versió 21). Per a l'anàlisi qualitativa hem dut a terme una anàlisi dels discursos trobats en les 5 últimes piulades pròpies de cadascun dels subjectes que hem identificat com a usuaris de Twitter. Només es mostraran les piulades més significatives per a l'anàlisi qualitativa, ordenades lògicament segons l'evolució del text.

\section{Anàlisi quantitativa dels resultats}

A continuació exposem els resultats obtinguts a partir de la nostra anàlisi, juntament amb la seua interpretació.

En la següent figura, quin és el patró d'ús lingüístic general dels polítics valencians quan fan servir Twitter:

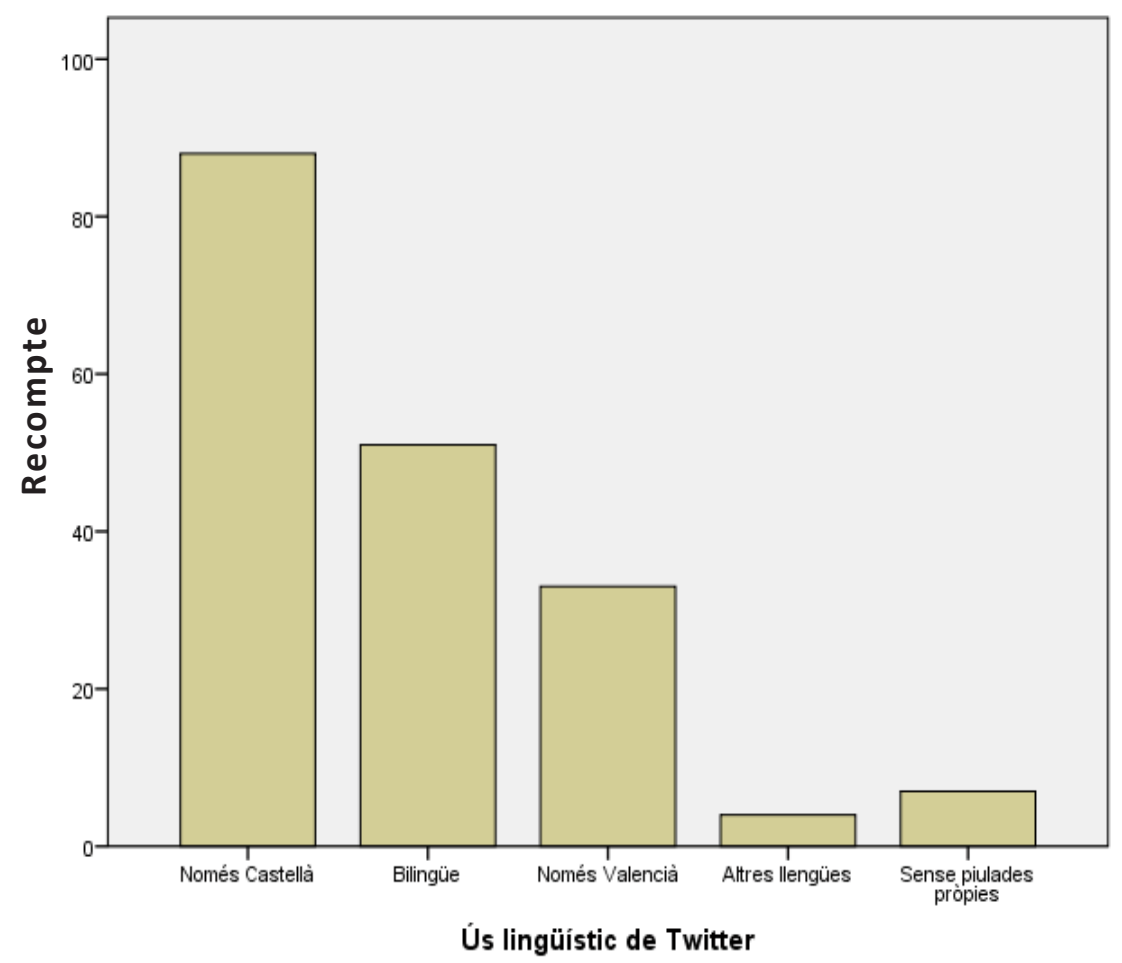

Figura 1. Gràfic de barres sobre la tria de llengua per part dels polítics valencians a Twitter ${ }^{1}$.

1 En totes les gràfiques del text, l'eix d'ordenades indica el número concret de polítics. 
Segons la figura 1, quant a l'ús general de les llengües a Twitter per part dels polítics valencians, la major part n'hi utilitzen exclusivament el castellà. Tanmateix, si sumem els polítics que fan un ús exclusiu del castellà i els que en fan un ús bilingüe castellà-català, superarien els usuaris monolingües del castellà. Aquest patró d'us al Twitter és coherent amb la situació sociolingüística del català al País Valencià, és a dir, el castellà hi és visiblement més present, tot $\mathrm{i}$ que el valencià resisteix amb força, amb una presència prou assentada, $\mathrm{i}$ el bilingüisme és indubtablement un comportament sociolingüístic normalitzat.

Tot seguit, ens centrem en les diferències trobades entre grups, d'acord amb les variables ja establertes en els nostres objectius. En primer lloc, s'observen les diferències que hem trobat d'acord amb la variable gènere:

\section{Gènere}

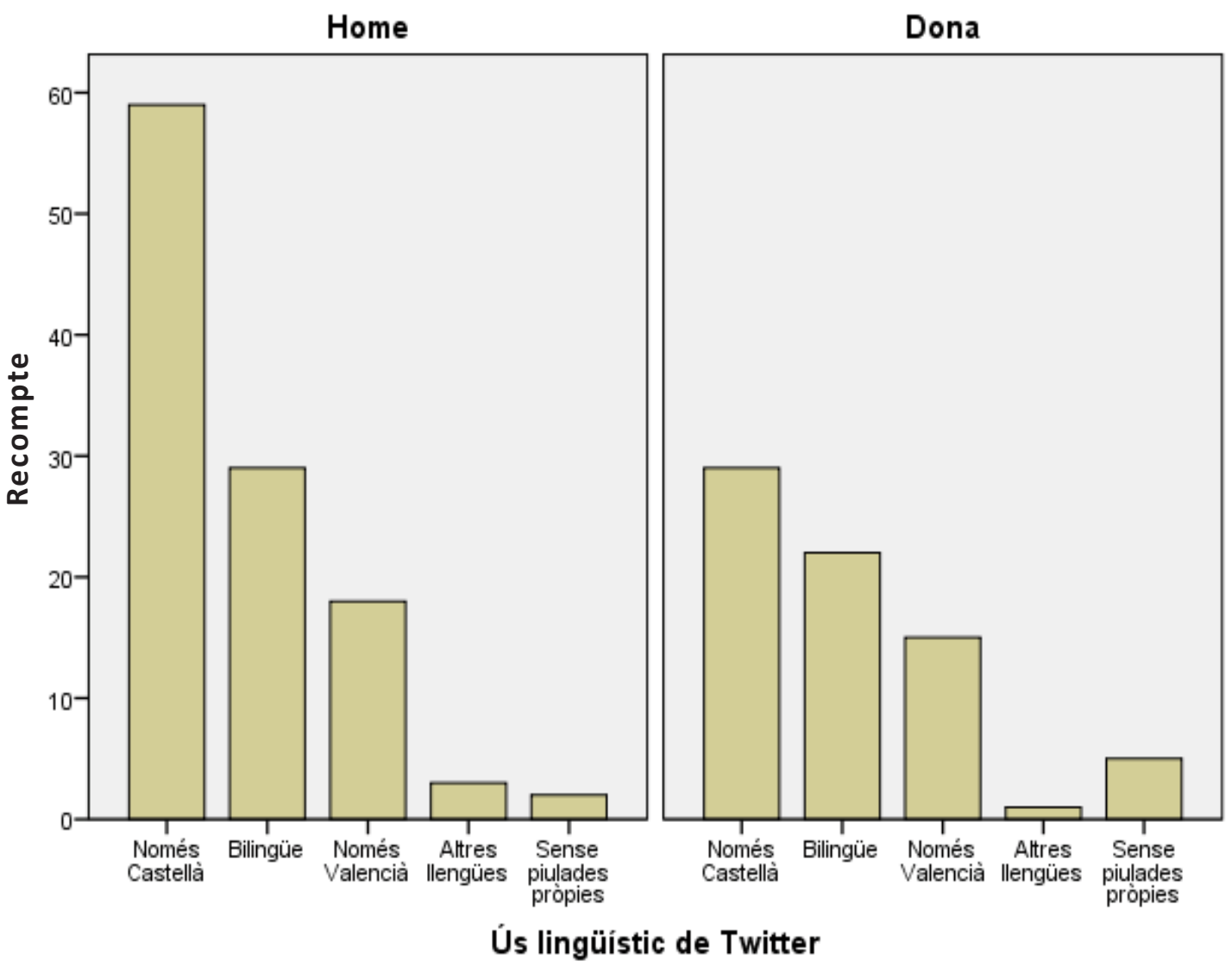

Figura 2. Gràfic de barres sobre la tria de llengua per part dels polítics valencians a Twitter segons el gènere. 
En la figura 2, s’ha observat que les dones polítiques fan més ús proporcionalment del valencià i del bilingüisme a Twitter que no els hòmens. En canvi, entre els hòmens es dispara l'ús monolingüe del castellà. Queda per aclarir si això és perquè en els partits d'esquerres militen més dones o és una qüestió d'ús lingüístic exclusivament lligada al gènere.

Una altra variable estudiada ha estat l'àmbit de la institució en què es troba cada subjecte. Els resultats d'aquest estudi han estat els següents:

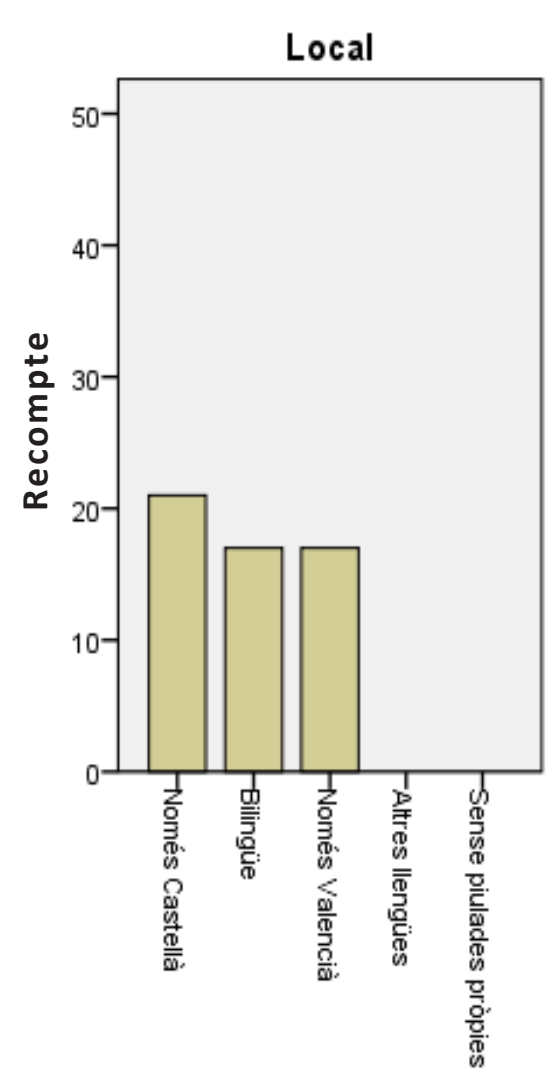

\section{Àmbit de la institució}

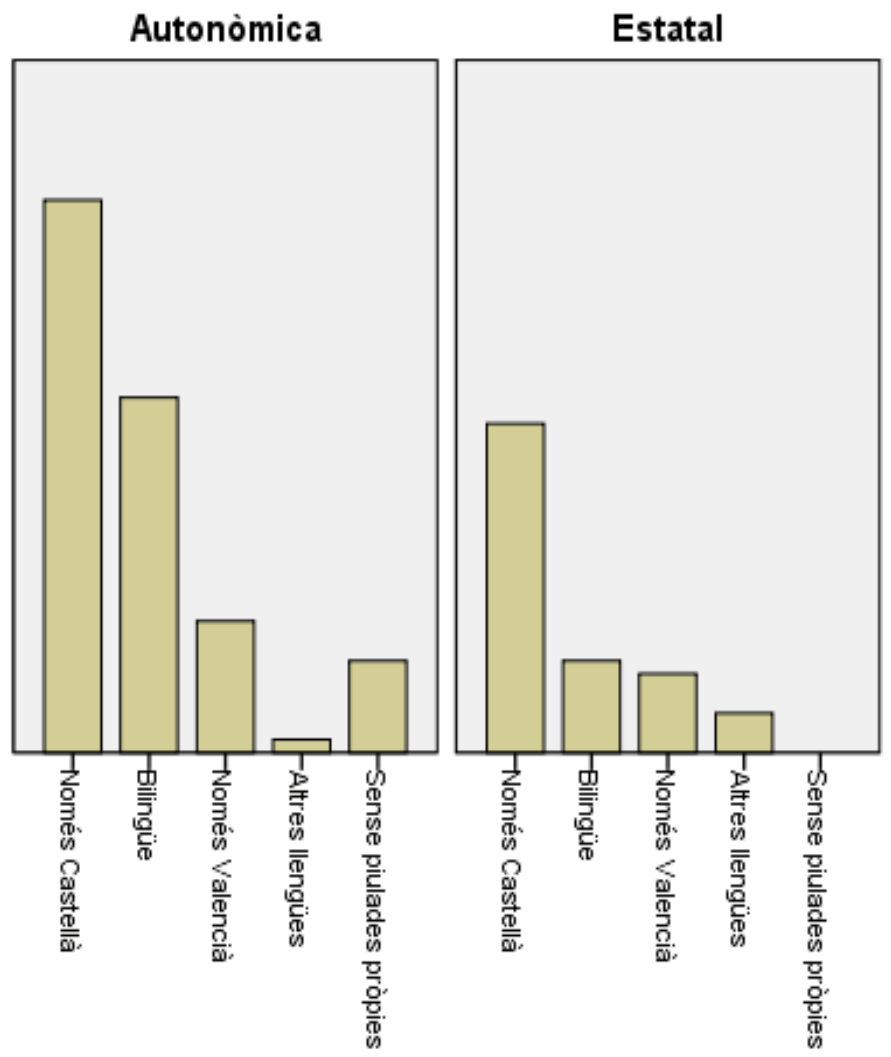

Ús lingüístic de Twitter

Figura 3. Gràfic de barres sobre la tria de llengua per part dels polítics valencians a Twitter segons l'abast de la institució política.

En relació amb la figura 3, segons l'àmbit de la institució política, hem observat que es fa servir molt de castellà a les Corts Valencianes malgrat que l'àmbit de la institució és valencià. En l'àmbit local, el pes del bilingüisme i del monolingüisme valencià és major que en l'autonòmic i en l'estatal. Podríem dir que tot es trasllada cap al valencià, en el sentit que alcaldes del PP opten pel bilingüisme (com ara Antonio Pérez, l'alcalde de Benidorm) i batlles i batllesses del 
PSPV opten pel monolingüisme valencià (com ara Tània Baños i Maria Josep Safont). El PP mai utilitza el valencià en l'àmbit estatal i en fa un ús escàs a les Corts Valencianes. En canvi, el bilingüisme no és tan estrany entre els alcaldes del PP, sobretot de poblacions més menudes. També s'observa que en l'àmbit estatal augmenta l'ús de l'anglès, que és gairebé inexistent en els altres àmbits.

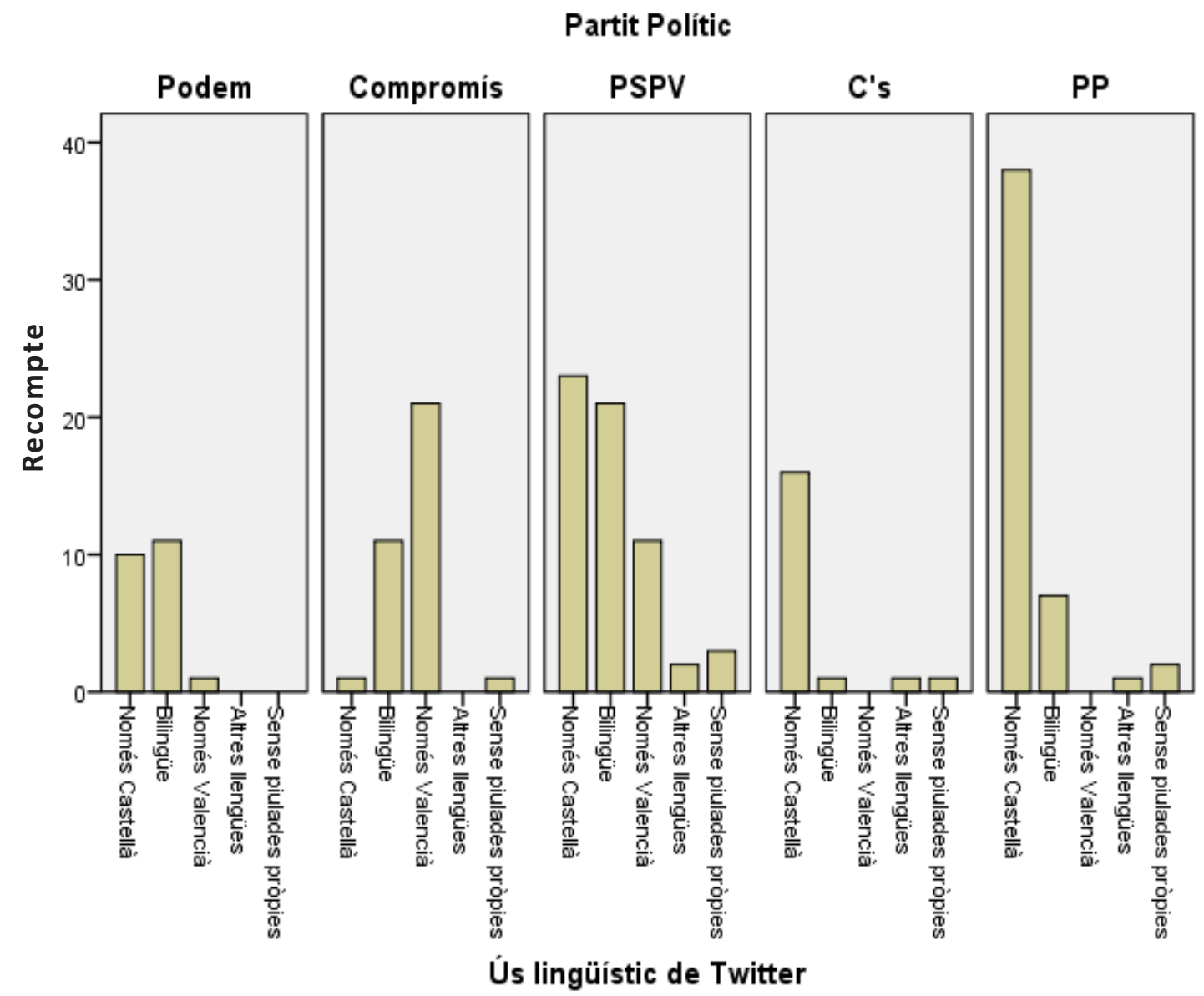

Figura 4. Gràfic de barres sobre la tria de llengua per part dels polítics valencians a Twitter segons la filiació.

Si observem la quarta gràfica, la classificació de les piulades segons llengua i filiació política, podem afirmar que Ciudadanos piula només en castellà en tots els àmbits, a excepció d'alguns tuits del cas excepcional del polític d'aquest partit Alexis Marí, que comentarem en el següent epígraf. El PP també fa un ús clarament predominant del castellà, malgrat que podem observar algunes conductes bilingües en uns pocs casos, quasi sempre en polítics d'àmbit local. Fet i fet, analitzant els usos lingüístics generals de cada partit en Twitter, observem que es tracta d'un reflex del model lingüístic que cadascun d'ells promou al País Valencià: Podem i el PSPV es 
regeixen per un model de bilingüisme més equilibrat, semblant al de Compromís, encara que en aquest últim la presència del valencià és clarament més forta. Finalment, veiem com en els partits més conservadors, el castellà té una clara preferència, especialment en el cas de Ciudadanos.

\section{Anàlisi qualitativa dels resultats}

Per a l'anàlisi qualitativa, hem escollit els següents 13 perfils de Twitter per la importància dels polítics en els seus càrrecs, tant de partit com públics, i perquè són els més actius a la xarxa social en qüestió segons el corpus que hem estudiat. Hi hem descartat, doncs, aquells polítics amb càrrecs importants però que no feien un ús significatiu de Twitter ni per freqüència ni per originalitat.

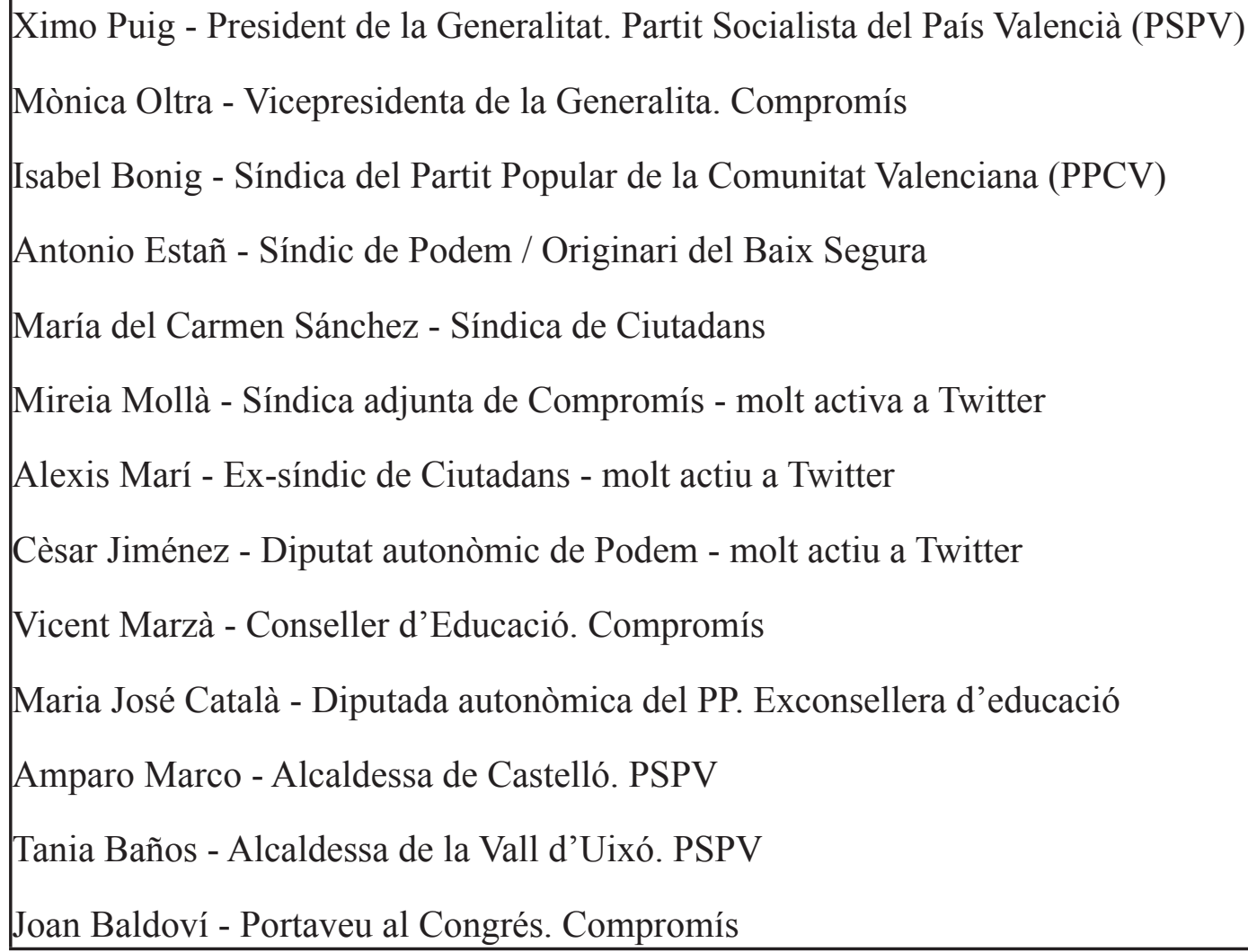

Figura 5. Perfils de Twitter de polítics valencians escollits per a l'anàlisi qualitativa. 


\subsection{Anàlisi qualitativa per categories temàtiques}

Hem escollit algunes de les piulades fetes per aquests polítics valencians en el període de temps que inclou els mesos de juliol a octubre de 2017. Els hem classificat per a l'anàlisi segons els temes valencians amb més ressò mediàtic sorgits durant aquests mesos.

\subsubsection{Catalunya}

a. Atemptats

Hem escollit tres piulades amb mostres de condol pels atemptats de les Rambles de Barcelona de l'estiu de 2017, un de Vicent Marzà (Compromís), un de Maria José Català (PPCV) i un d'Antonio Estañ (Podem). El de Marzà està escrit en català, com era esperable d'un polític de Compromís dirigint-se als catalans. El d'Estañ està en català, tot i que ell sempre escriu en castellà ja que és del Baix Segura, zona valenciana de predomini lingüístic espanyol. Amb aquest gest, Estañ tracta d'empatitzar amb els catalans en un moment molt sensible. Per això utilitza la llengua pròpia tot i que no és la seua. En canvi, Maria José Català, exconsellera d'educació, expressa el condol en castellà, llengua d'ús habitual del seu Twitter, seguint amb la línia discursiva i ideològica del seu partit. En canvi, Ximo Puig (PSPV) escriu un condol pel terratrèmol a Mèxic i ho fa amb un text en català i una etiqueta en castellà.

Vicent Marzà. Guanyarem: amb la fermesa dels valors compartits, la solidaritat per bandera, la cultura i l'antídot d'educar per la pau. A Barcelona o Alep.

Antonio Estañ. De camí a Barcelona per a demostrar tot el nostre suport. En front del terror, la solidaritat d'un poble valent i acollidor. \#NoTincPor

Ximo Puig. Seguim amb preocupació les notícies que arriben des de Mèxic. La nostra solidaritat i el condol amb les víctimes i familiars \#FuerzaMexico

b. La Diada de Catalunya, 11 de setembre de 2017

En relació amb aquest tema, citem un tuit de la portaveu de Ciudadanos (que sempre fa servir l'espanyol) en el qual, amb l'ús del castellà, tracta de vincular la llengua catalana amb el separatisme. D’altra banda, Estañ torna a fer ús del català per a parlar de Catalunya. El seu tuit s'enfoca en termes de drets civils, de sobirania popular, en lloc de parlar de separatisme. 
Mari Carmen Sánchez. La diada debería ser el día de todos los catalanes y no sólo la de aquellos que dicen SÍ al separatismo y a la ilegalidad. \#caminemosjuntos

Mari Carmen Sánchez. \#NoNosCallaran a aquellos que queremos una España sin escisiones, libre y plural, donde la auténtica democracia sea nuestro estandarte [i apareix una imatge d'una pintada on diu "Ciudadanos, no és la vostra terra"]

Antonio Estañ. Dia de celebració i reivindicació de la sobirania popular, diada dels catalans i catalanes. Feliç \#Diada2017!

\subsubsection{Educació}

a. La qüestió del plurilingüisme i dels decrets educatius

L'exconsellera d'educació Maria José Català (PPCV) piula sempre en espanyol contra el tema del plurilingüisme. És usual per part del PPCV i de Ciudadanos anar en contra del model de plurilingüisme a les escoles valencianes que proposa el Consell a través de tuits escrits en espanyol. A banda d'això, són paradoxals algunes piulades d'Alexis Marí, polític escindit de Ciudadanos, criticant les actituds negatives cap a la llengua, que ell mateix manifesta de vegades. Tanmateix, des que Marí és diputat no adscrit, fa comentaris a favor de la llengua i de l'educació en valencià, sembla que per contradir la línia del seu antic partit, Ciudadanos. En un altre tuit, fa broma amb la seua dona, Carolina Punset (famosa per l'episodi mediàtic d'autoodi en què va titllar el valencià d'aldeano) sobre la possibilitat d'estudiar en valencià moltes més hores amb el nou model.

Alexis Marí. Escolta,@CarolinaPunset, en tres cursos ja pots matricular a la nostra filla amb 8h de valencià. Digues-me que estàs bé [icona de rialla]

Alexis Marí. Quan no hi ha voluntat d'aprendre també es nota.

b. Inici del curs escolar 2017-2018

El president de la Generalitat Ximo Puig (PSPV), que tuiteja sovint en castellà, escriu en valencià un tuit en valencià carregat d'emocions sobre l'alumnat que s'incorpora per primera volta a les aules el curs 2017-2018. Sobta en aquest tuit que, tractant-se d'un tuit del president del govern sobre educació, continga una paraula mal escrita (il·lusió). D’altra banda, hi fa un altre tuit en espanyol sobre el balanç de les polítiques educatives del Consell, però en el qual 
trobem el nom en valencià del programa Xarxa Llibres, el qual la Conselleria d'Educació va batejar únicament en valencià, sense necessitat de traducció.

Ximo Puig. Hui 754.613 xiquets/etes enceten un nou curs amb il.lussió per aprendre, amb alegria de construir afectes que ho seran per sempre. Ànim!

Ximo Puig. El lunes arrancamos curso escolar con:

+ profesores

- alumnos/as

Xarxa Llibres

Cremona adjudicado

Encara es destaca un tuit de Mònica Oltra contestant en castellà contestant un seguidor del PP sobre informació falsa sobre la gestió de la Conselleria d'Educació. Tot i el que a priori es podria esperar, Mònica Oltra (Compromís) no només fa servir el valencià a Twitter. Potser és en castellà perquè es tracta d'una resposta a una acusació prèvia feta pel PPCV.

Mònica Oltra. "Retuit: El PP valenciano obtuvo su mayor lucro con la construcción de colegios”. Crédito que la UE dio a su partido, el PP, en 2008 y ese dinero no se empleó para colegios. ¿Para qué lo empleásteis?

\subsubsection{Festes}

\section{a. Festes tradicionals}

En aquest cas, tenim l'exemple de la síndica del PP Isabel Bonig, que ha utilitzat Twitter per fer publicitat de les festes populars que ha visitat durant l'estiu. És curiós com, tot i que ella hi utilitza quasi exclusivament el castellà, fa ús del valencià en aquestes situacions de tipus folklòric (dos tuits, un a Benaguasil i un altre a Carlet). No obstant això, també a Carlet informa en castellà quan fa referència a un acte catòlic com és la processó de Santa Maria. De fet, els polítics del PPCV tendeixen a fer servir el valencià per a temes folklòrics.

Isabel Bonig. Compartint les festes a Benaguasil [careta de clucada d'ull]

Isabel Bonig. \#BonaNit des de Carlet en la nit dels mantons de Manila [icona de careta somrient]

Isabel Bonig. \#FelizViernes desde la procesión de Santa María de Carlet. 


\section{b. Bonica Fest}

Mònica Oltra, juntament amb el regidor de comerç de València Carlos Galiana, visiten per segon any consecutiu (2016-2017) els mercats municipals de valència durant la nit del Bonica Fest, iniciativa en què es fan concerts als mercats del cap i casal. La vicepresidenta hi piula tant en castellà com en valencià tot remarcant-ne la interessant oferta artística $\mathrm{i}$ gastronòmica. Concretament, al barri de Jesús ho fa en castellà, mentre que al barri de Russafa ho fa en valencià. Mentre que el de Jesús és un barri de l'eixample industrial construït per ubicar treballadors migrants i que per aquesta raó és més habitual que trobem castellanoparlants, Russafa és un barri recentment gentrificat on la classe mitjana que hi predomina sol tindre un nivell sociocultural més alt i on per tant s'està recuperant el valencià.

\begin{tabular}{|l} 
Mònica Oltra. Seguim de ruta \#BonicaFest cap al mercat de Russafa \\
\hline Mònica Oltra. Parada y fonda en el Mercado de Jesús \#BonicaFest
\end{tabular}

Hem trobat una actitud lingüística semblant en dos tuits de la batllessa de la Vall d'Uixó, que quasi sempre tuiteja en valencià però que canvia al castellà en referir-se al barri de Toledo, un barri de la seua localitat, a propòsit d'una celebració popular.

Tània Baños. Ja estem en penyes!!! A disfrutar de la setmana de festes \#lespenyesenfestes \#lavallduixo

Tània Baños. Disfrutando del concurso de paellas del barrio de Toledo \#paella \#fiestas

Mireià Mollà (Compromís) també és assídua a fer servir el valencià a les xarxes. Però tal com fan Oltra i Baños, en referir-se a una població amb un biaix demogràfic suposadament castellanoparlant, no dubten a piular en castellà. En aquest cas, Mollà ho fa a propòsit del barri de San Antón d'Elx, citant el tuit en valencià de la Generalitat Valenciana en què s'amplia la informació. Hem vist, doncs, tres exemples de com, en dirigir-se a barris obrers sorgits durant la industrialització de la segona meitat del segle XX, es fa servir el castellà fins i tot per part de polítiques activistes pel valencià. 


\section{c. Efemèrides}

Amparo Marco (PSPV) felicita la ciutat de la qual és batllessa, Castelló, pels 766 anys de la seua fundació amb un tuit en valencià. La ciutat és de predomini valencianoparlant. L'alcaldessa sol tuitejar en les dues llengües oficials. Tanmateix, tuiteja en castellà sobre la commemoració dels 100 anys de l'IES Francesc Ribalta, el més antic i emblemàtic de la ciutat, lligat al Castelló liberal de finals del segle XIX, de tradició intel·lectual en espanyol.

Amparo Marco. Enhorabuena al Instituto Ribalta por 100 años de creación de futuro en nuestra ciudad. Merecida medalla de oro de \#Castellon@AjuntCastello

Amparo Marco. Felicitats a totes i tots!!! \#Castello766anys

\subsubsection{Valencianisme}

a. Patriotisme

Aquesta qüestió s'enfoca des de diferents perspectives i llengües. D'una banda, des de Compromís, Oltra i Mollà parlen explícitament de patriotisme en valencià, però especificant que entenen aquest concepte des d'una dimensió social i no de banderes. Bonig parla en castellà dels interessos dels valencians, sense especificar i sense parlar de patriotisme explícitament, segurament perquè, des del seu marc ideològic, el patriotisme no es pot entendre en un sentit únicament valencià, i menys encara quan el seu partit (PPCV) es posiciona identitàriament als antípodes del valencianisme, amb el castellà com a llengua d'identificació, tot relegant el valencià a un àmbit lúdic o familiar.

Mònica Oltra. El nostre patriotisme és el de la gent, el del poble, el de fer-li la vida més fàcil a les persones.

Isabel Bonig. Comenzamos hoy el Debate de Política General en les @cortsval. El @ppcv defenderá una vez más el interés de todos los valencianos.

Mireia Moià. En @iniciativapv parlem de política: com fem una política on el patriotisme no és la bandera, és la gent i millorar les condicions de vida.

b. Finançament

Baldoví, diputat i portaveu de Compromís al Parlament, utilitza el castellà a Twitter sovint, però d'una manera curiosa, i és que fa algunes piulades dues vegades, una en cada llengua. 
Baldoví ha estat una de les figures clau en la campanya per la millora del finançament del País Valencià que s'implementa des del seu partit i, a més, sol piular sobre qüestions estatals. En un altre dels exemples, tenim un tuit del Conseller d'Educació en valencià on li'n retuiteja a Baldoví un en castellà. Com veiem, es tracta de diferents opcions de bilingüisme en els discursos interactius de Twitter.

Joan Baldoví. Espanya ha perdut en el rescat bancari tants diners com Alemanya, Regne Unit, França i Itàlia juntes. Crisi o estafa? / España ha perdido en el rescate bancario tanto dinero como Alemania, Reino Unido, Francia e Italia juntas. ¿Crisis o estafa?

Vicent Marzà. Vicent Marzà. Fil de @joanbaldoví: que s'acostumen a veure’ns reclamar. El poble valencià ja no baixa la cara. Volem un \#tractejust [retuit d'un tuit de Baldovi en què diu: "Dice Montoro que los valencianos solo hacemos que llorar por reclamar un \#tractejust"]

\subsection{5. À Punt}

Sobre la nova RTVV, un altre motiu de disputa a la cambra autonòmica, en tenim diverses, de piulades interessants per a l'anàlisi. Com que l'objectiu d'aquest treball no és analitzar en si la confrontació, sinó l'ús de la llengua, hem seleccionat dos tuits favorables al nou canal, en valencià, en els quals es dona una perspectiva de futur de la llengua, relacionant-la amb les noves tecnologies i amb l'educació (i no amb qüestions tradicionals o folklòriques, ni tampoc parlant explícitament d'identitat). Els autors dels tuits són el Conseller Marzà (Compromís) i el diputat Jiménez (Podem). En el cas del segon, de nou s'inclou l'humor.

Vicent Marzà. Una eina imprescindible per al sector cultural, la llengua i per tindre informació veraç i propera. Avança@apunt_media

César Jiménez. Noves tecnologies de l'audiovisual, plataformes multimèdia, streaming, edició gràfica, mobiliari nou... Tot \#àPunt [i repiula una notícia amb el titular "Els ex-RTVV copen els primers llocs per a À Punt"]

\subsubsection{Turisme}

El turisme ha estat tema clau en el model econòmic del País Valencià durant els últims anys, i per tant s'esdevé un cert ressò mediàtic quan s'aproven normatives sobre aquest tema, com és el cas de la nova taxa turística. Ací ens trobem de nou amb polítics que opten pel castellà (Amparo Marco, alcaldessa de Castelló i Isabel Bonig, Síndica del PPCV) i altres que ho fan 
pel valencià (Cèsar Jiménez o Tania Baños). Amparo Marco hi utilitza les dues llengües, però en parlar de turisme fa ús del castellà. De fet, hem observat aquesta preferència pel castellà en alguns polítics del PSPV com Marcos o Puig en parlar de temes empresarials i de negoci, tot demostrant una actitud diglòssica que no secunden altres polítics del PSPV com ara Tània Baños. César Jiménez (Podem) fa servir el valencià en moltes ocasions i no canvia al castellà en el cas del turisme. Tampoc ho fa Tania Baños, que inclús parla en valencià de llançar turísticament al País Valencià per tot el territori nacional.

Isabel Bonig. Alto y claro [i repiula un text d'opinió que diu "Porque el turismo nos importa y porque no es momento de ponerle trabas al sector más importante de nuestra economía \#elppCVdiceNOalaTASA"]

Alexis Marí. Podemos presiona: tasa regional a los hoteles, caravanas o cruceros de 0,5 hasta 5 euros. Me parece muy bien!

César Jiménez. Caminant cap a la implantació de l'impost per l'activitat turística a les nostres comarques. Ara cal empentar els que encara no creuen.

\subsubsection{Pacte Valencià contra la violència de gènere}

Semblantment al turisme, el tema de la violència contra la dona és aliè a allò cultural $i$ a allò lingüístic, però de gran importància per la seua transversalitat (qualsevol persona pot ser potencialment víctima de violència masclista) i l'actualitat. No han estat pocs els polítics que s'han fet ressò d'aquest pacte. En aquest cas, els polítics de Compromís i el President ho van fer en valencià, mentre que Antonio Estañ, originari del Baix Segura, ho va fer en la seua llengua materna, el castellà.

Joan Baldoví. Tots i totes hem de lluitar contra la violència masclista \#SumatalPacte

Antonio Estañ. Todos los partidos juntos y muchos agentes de la sociedad civil firmamos el Pacto Valenciano contra el Machismo. El feminismo se abre paso.

Mireia Mollà. Jo també m'he sumat al Pacte valencià contra la violència de gènere i masclista. Vos anime a signar i difondre. 


\subsection{Anàlisi qualitativa d'altres aspectes discursius}

\subsubsection{Els canvis de codi}

Per a aquest epígraf, s'han seleccionat alguns tuits en què es fa servir més d'una llengua. Trobem l'ús del valencià com a recurs humorístic o ruralitzant? Quant a l'ús de l'espanyol i del català, Marian Campello, diputada autonòmica de Compromís, sobre l'assetjament escolar elabora un text en què els insults apareixen en castellà, tot assignant l'assetjador la llengua de Cervantes.

Marian Campello. Molts intentaren buscar-me la tara, “que eres gordita? La empollona?” Miren no, la tara no era meua... \#Acosoescolar

En un altre tuit en el qual vol desacreditar unes informacions dona del pel PP, escriu en valencià la contextualització però es passa al castellà per apel·lar directament a la diputada que els ha atacat. De nou utilitza el castellà com a llengua de qui ella possiblement considera un enemic, tot instrumentalitzant la llengua per a la introducció del punt de vista ideològic.

El cas de Marzà és paregut. Podria tractar-se de la creació d'un antagonista polític castellanoparlant (que va contra les polítiques valentes, les emocions o les passions alegres). Aquesta construcció de l'antagonista per mitjà del canvi de codi només s'ha trobat en el nostre corpus pel que fa a polítics de Compromís.

Vicent Marzà. "La izquierda no sabe gestionar el dinero, no hace nada por los autónomos", un altre tòpic de la Gürtel que cau [repiula una notícia amb el titular "La comunidad reduce la espera de los autónomos para cobrar del 95 al 55"]

Mari Carmen Sánchez, síndica de Ciutadans a les Corts, sempre fa servir el castellà, però en aquest cas utilitza un hashtag en valencià, \#BonDia, que no fa referència a contingut sino que és una qüestió pragmàtica, gairebé decorativa.

Mari Carmen Sánchez. Seguimos creciendo y seguimos trabajando. \#BonDia y \#FelizLunes

En relació amb l'ús del català i de l'anglès, Mònica Oltra (I <heart> \#XarxaLlibres), escriu un tuit dient que estima la mesura de reutilització de llibres de la que hem parlat abans, 
introduint l'anglès. La utilització de la que sol ser la llengua franca arreu el món sol donar més prestigi, encara que ací sembla més una qüestió de joc lingüístic a partir d'un referent fraseològic anglès popularment conegut.

\subsubsection{L'humor}

Poell i Darmoni (2012), en estudiar els usos de Twitter durant la primavera àrab a Tunísia, varen observar que les llengües minoritzades de la zona es feien servir preferiblement en les piulades amb humor i ironia. Aquest ús diglòssic l'hem trobat en alguns casos en usuaris valencians de Twitter pel que fa al català.

Antonio Estañ fa, en castellà, una broma sobre el nou topònim oficial de la ciutat de valència. Hi insinua que el canvi fonètic produït per l'accent obert pot donar problemes, i en culpa l'independentisme. Juga amb el tòpic que les llengües perifèriques de l'Estat espanyol creen anhels separatistes.

Com d'ha apuntat, el diputat Jiménez sol també fer ús del valencià en un to humorístic en el seu Twitter. Es tracta d'un exemple de normalització de la llengua a través de l'humor i de la transversalitat temàtica en el eixe ús.

Quant als límits de l'humor en Twitter, el cas d'Enric Nomdedéu és paradigmàtic d'un polític que, pel fet d'ocupar un càrrec tècnic a l'administració pública, en aquest cas ser cap del SERVEF, ha de moderar el seu to de crítica sarcàstica en Twitter perquè, si no, és atacat per l'oposició i pels periodistes. En l'últim any i des que ocupa l'esmentat càrrec, Nomdedéu s'ha hagut de desdir de diverses piulades, entre elles, les més destacades en són una sobre l'estat físic de l'antic president popular valencià Eduardo Zaplana i l'altra sobre la líder del PP valencià Isabel Bonig, en què sembla que la compara amb un simi, fet que s'ha titllat de masclista.

Enric Nomdedéu. El País Valencià és un lloc fantàstic, s'escapa una vaca a Borriana, apareix una cabra a l'hospital de València i hui he vist Zaplana.

[Fil]: Costava de reconèixer. Sense nas i sembla que la malaltia el consumeix, molt deteriorat.

Enric Nomdedéu. El PP voldria canviar a Bonig, però l'alternativa és un ximpanzè amb una ballesta. 
Compartim amb Poell i Darmoni (2012) la idea que la narració i el relat personal es fan servir sovint per alguns polítics valencians en els seus comptes de Twitter, així com l'ús de l'anècdota personal com a mecanisme d'identificació amb el votant entre els polítics. Ho hem observat especialment en els casos de Mireia Mollà i de Tania Baños, que són dones i polítiques de les més joves del panorama valencià.

Mireia Moià. Lo que no se ve en el debate de política general son los selfies modo \#Botànic. Marta-Barceló @ SocialistesVal, Ferri-Mollà @Compromis, Estañ-Meco@Podem

Segons Hong, Convertino i Chi (2011: 520), «we assume that the number of hashtags commonly used by a pair of language communities indicates how likely these two communities were to post messages about the same tòpics». En el cas dels polítics valencians, hem constatat que moltes de les etiquetes sobre qüestions polítiques de les quals opinen són les mateixes. Per tant, els temes i les converses sobre política valenciana estan connectats en les dues llengües oficials. Tanmateix, sí que trobem etiquetes diferents depenent del biaix ideològic, com hem vist, per exemple en el tema del procés sobiranista català.

\section{Conclusions}

Aquest estudi, tot i amb les seues limitacions, ens revela un cert patró d'usos lingüístics en una esfera tan nova com és la de les xarxes socials. Hem observat com el biaix ideològic no és l'única variable que té incidència en aquest patró, ja que sembla que l'àmbit local, autonòmic o estatal de la institució és també decisiu. Tot i així, aquest patró representa, d'acord amb el nostre criteri, un reflex del model lingüístic que cadascuna de les forces polítiques estudiades sembla promoure per al País Valencià.

En els polítics del PSPV, sembla que hi predomina l'ús al 50\% del castellà i del valencià en les intervencions a Twitter, tot implementant una mena de bilingüisme paritari. També hem detectat un canvi de codi segons el tema que es tracta en alguns polítics com ara Ximo Puig, que utilitza el castellà predominantment en qüestions d'empresa o de turisme (tractament diglòssic). Això coincideix amb la recerca de Kim et al. (2014: 5), que han observat que els usuaris bilingües 
piulen sobre temes diferents segons la llengua utilitzada: «bilinguals express informative/political/ debatable topics in a local language, while posting event/tour/enjoyment topics on the English».

Hem constatat també que els usos lingüístics són semblants entre els polítics de Podem País Valencià i del PSPV, malgrat el biaix polític a priori més esquerrà de la formació morada. De fet, en molts temes identitaris acaben coincidint per causa de condicionaments provinents de les direccions centralistes d'ambdós partits.

Hem destacat el cas paradoxal de tendència sociolingüística d'Antonio Estañ, líder de Podem al País Valencià que, tot i provenir d'un territori castellanoparlant com és el Baix Segura, on les actituds lingüístiques envers el valencià són molt negatives, ha optat per una actitud lingüística positiva cap al valencià, que normalment expressa en castellà. Tanmateix, com ja hem apuntat en treballs anteriors (Bellido i Monferrer, 2015), no sempre cal expressarse en valencià per generar actituds lingüístiques positives envers la llengua minoritzada. De l'altra banda, no sempre que s'utilitza el valencià es generen actituds lingüístiques positives envers aquesta llengua, tal com demostràvem amb els discursos folkloritzants de Canal $9 \mathrm{i}$ de la Televisió d'Astúries (ibídem).

Finalment, podem afirmar que Compromís és el partit que més fa servir el català de l'arc parlamentari valencià. Els alcaldes de Compromís fan un ús pràcticament exclusiu del valencià en les seues piulades, tot i que els polítics, com Joan Baldoví, que treballen en el Congrés dels Diputats de Madrid, en fan un ús predominantment bilingüe. Aquest fet denota una consciència de canvi de receptor per part del polític, que ja no es dirigeix solament als seus votants, sinó que també fa d'altaveu per a la premsa estatal (pensem en l'elevada presència de Baldoví en televisions estatals com La Sexta o en el fet que haja sigut el polític nacional més ben considerat) ${ }^{2}$, i compta amb polítics i periodistes estatals i interessants en la política de tota Espanya com a públic objectiu afegit del seu discurs a Twitter.

2 Disponible a: < https://www.diarilaveu.com/noticia/81623/baldovi-politic-mes-valorat-estat-espanyol> [Última consulta: 10/03/19]. 
Podem afirmar que s'han complert els objectius establerts a l'inici d'aquest treball. S'han trobat diferències entre grups polítics quant a la tria lingüística i el contingut discursiu de les seues piulades. Tornant a les hipòtesis, fet i fet, sembla que es confirmaria l'existència d'una correlació entre les variables orientació ideològica i ús lingüístic entre els polítics valencians, salvant alguns matisos suara comentats.

En darrer lloc, quant a la segona hipòtesi, hem observat que existeix un silenci per part dels polítics valencians envers el tema del procés sobiranista català. Per tant, el silenci o silenciament d'un tema també té significat. En aquest cas, és especialment curiosa la manera d'eludir aquest tema per part dels partits valencians d'esquerra per por al rebuig social o a la contraargumentació ferotge del PP en aquest tema. El PP sí que treu el tema i ho fa per atacar Compromís; per tant, Compromís evita l'activació del marc conceptual del pancatalanisme per tal de bloquejar la contrarèplica de l'oposició conservadora, seguint la teoria de l'activació dels marcs de referència de Lakoff (2004). Compromís s'esforça per parlar del nacionalisme només a partir de temes com ara el dèficit del finançament o bé els drets socials dels ciutadans (treball, habitatge...), sempre ometent cap referència pancatalanista que es puga convertir en una arma de doble tall. En el fons, encara queda el solatge de les tensions antivalencianistes.

Quant a futures recerques, com afirma Shirky (2016: 35), «little political change happens without the dissemination and adoption of ideas and opinions in the public sphere. Access to information is far less important, politically, than access to conversation». Per tant, serà important que es cree interacció en català a Twitter, cosa que pronostiquem possible atés que en la conversa real en aquest territori, el canvi de codi és una qüestió totalment habitual.

Altres elements que podrien analitzar-se semblantment en els perfils dels polítics a Twitter són les repiulades, l'evolució dels fils de conversa, els hashtags o etiquetes i els textos que mantenen com a presentacions en el seu perfil o bé com a tuits fixats just després e la presentació. Per tant, encara queden moltes possibilitats de recerca en aquest camp que nosaltres en aquest article simplement hem pretés esbossar. 
De fet, sovint allò estrany hi és la conversa monolingüe. Destaquem també que l'interés de l'anàlisi de la repiulada entre els polítics. Hi ha maneres diferents de retuitar (Boyd, Golder i Lotan, 2010: 1):

While retweeting can simply be seen as the act of copying and rebroadcasting, the practice contributes to a conversational ecology in which conversations are composed of a public interplay of voices that give rise to an emotional sense of shared conversational context. For this reason, some of the most visible Twitter participants retweet others and look to be retweeted. This includes users of all kinds, but notably marketers, celebrities and politicians.

Si es repiula molt un polític serà perquè és influent. Per ara, hem observat que les repiulades entre polítics solen ser endogàmiques. Algunes excepcions serien Alexis Marí amb intenció provocadora o bé alguns dels membres del govern tripartit entre ells per tal de difondre una imatge de cohesió entre els membres del govern.

En el cas dels polítics, podríem considerar dos tipus d'ego retuits: els retuits de piulades on apareix explícitament esmentat el polític que repiula, que no són molt abundants, i els retuits sobre qüestions relacionades amb el seu partit o amb els seus companys de partit, que ocupen un espai central en els comptes de Twitter de gairebé tots els polítics, com en el cas explicat del Pacte contra la violència de gènere, però açò ja són figues d'un altre paner. 


\section{Bibliografia}

Bellido, T. C. i Monferrer, A. (2015). «Media and minority languages: a comparative study of Asturian and Valencian contexts», en International Conference on Linguistics of IberoRomance Languages, pp. 13-14. Gant: Universitat de Gant. Abstract.

Boyd, D., Golder, S. i Lotan, G. (2010). «Tweet, Tweet, Retweet: Conversational Aspects of Retweeting on Twitter», en HICSS-43, pp. 1-10. Disponible a: <https://www.danah. org/papers/TweetTweetRetweet.pdf>

Gifreu, J. (2014). El català a l'espai de comunicació. Barcelona: Aldea global.

Hong, L., Convertino, G. i Chi E. H. (2011). «Language Matters in Twitter: A Large Scale Study», en Proceedings of the Fifth International AAAI Conference on Weblogs and Social Media, pp. 518-521. Disponible a: <https://www.aaai.org/ocs/index.php/ICWSM/ ICWSM11/paper/viewFile/2856/3250> [Última consulta: 10/03/19].

Kim, S., Weber, I., Wei, L. i Oh, A. (2014). «Socioliguistic Analysis of Twitter in Multilingual Societies», en Proceedings of the 25th ACM conference on Hypertext and social media, pp. 243-248. Disponible a: <https://dl.acm.org/citation.cfm?id=2631824> [Última consulta: $10 / 03 / 19]$.

Lakoff, G. (2008). Don't think of an elephant! Vermont: Chelsea Green Publishing.

Nobajas, A. (2016). «Twitter com a eina per a la recerca sociolingüística: llums i ombres», en Treballs de Sociolingüistica Catalana, Volum 26, pp. 89-101.

Plataforma per la Llengua (2017). «InformeCat 2017. 50 dades sobre la llengua catalana». Barcelona: Plataforma per la llengua. Disponible a: <https://www.plataforma-llengua. cat/media/upload/pdf/informecat-2017_1494432364.pdf> [Última consulta: 10/03/19]. 
Poell, T. i Darmoni, K. (2012). «Twitter as a Multilingual Space: The Articulation of the Tunisian Revolution Through \#Sidibouzid. NECSUS», en European Journal of Media Studies, Volum 1.

Shirky, C. (2016). «The Political Power of Social Media: Technology, the Public Sphere and Political Change», en Foreign Affairs, Volum 90, pp. 28-41.

Suh, B., Hong, L., Pirolli, P. i Chi, E. H. (2010). «Want do be Retweeted? Large Scale Analytics on Factors Impacting Retweet in Twitter Network», en International Conference on Social Computing, pp. 177-184. 